\section{DANDELION}

postgraduate arts journal \& research network

VOLUME 4 NUMBER 2 WINTER 2013
REBECCA WRIGHT is a PhD candidate at the London Consortium, Birkbeck College. Her AHRC-funded research explores the rhetorical function of energy in the early twentiethcentury life sciences and cultural field. Her writing has featured in Studio International and E.R.O.S. and she was a researcher on the World Energy Council history project. She is a 20132014 AHRC fellow at the Library of Congress. She is also the London Consortium contact for the Science Museum Lates and produces radio shows for The Thread on Resonance FM.

rwrigh02@mail.bbk.ac.uk

Article

\title{
The Cock and the Weathercock: The Circular Value of the Wind
}

\author{
Rebecca K. Wright
}

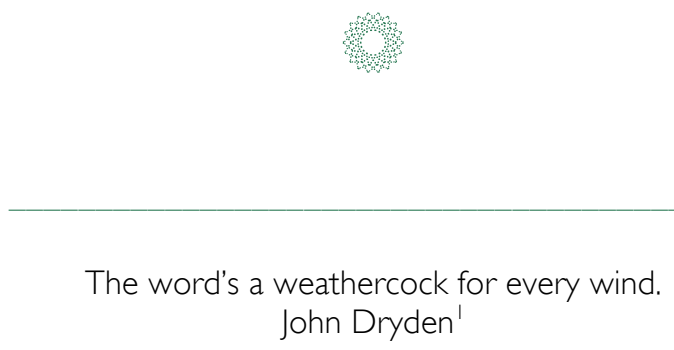

In Herman Melville's Short story 'Cock-A-Doodle-Doo, Or The Crowing of the Noble Cock Beneventano' (1853), the narrator, heavily in debt and burdened by illfortune, unexpectedly hears a cock crow. Surprised, he asks himself, 'did ever such a blessed cock-crow so ring out over the earth before! Clear, shrill, full of pluck, full of fun, full of glee. ${ }^{2}$ Obsessed and enlivened by this crow, the narrator sets out to find the blessed cock. When the narrator eventually finds the bird in the care of Merrymusk (the poor wood-sawyer), to his dismay he cannot purchase it; he watches aghast as Merrymusk and his family die one by one, followed by the Noble Cock Beneventano. As well as referencing Christ's crucifixion and resurrection, the story is an allegory for the quest of the Holy Grail: to the narrator, the noble crow signifies the attainment of all value. ${ }^{3}$ Yet, in this fable of failed Salvation, the death of the cock denotes a world in which all value and predestination is lost. If the cockerel cannot grant salvation, the narrator is left to ask, where now does value lie $?^{4}$

The name of Melville's cock, Beneventano, which means 'good wind' in Italian, points to the shared cultural history of the wind and the cock, united in the 
meteorological instrument of the weathercock. Since Aristotle's Meteorologica the wind has been read as a powerful portent of the Gods, be they mythological or theological. This was central to Old Testament writing, which correlated the 'Wind as God and God as Wind'. ${ }^{5}$ When translated, the Hebrew word ruwach meant spirit, breath or wind. This was used throughout the Old Testament, making the wind the vehicle for both a creative and vengeful God. Similarly it centred the wind in the Creation myth as that which begot value. ${ }^{6}$ A stand in for the 'breath' of God, the current of air became a central agent in allocating meaning in a theocentric value system. ${ }^{7}$ Its arrival, strength and direction told of those to be blessed, punished or forgiven. ${ }^{8}$ Honoured as the 'breath of God', the wind epitomised the allocation of theological value in an undressed world. This need to impose a subjective value on the wind was integral because, Bryan Watson points out, we only know the wind 'indirectly' by its affect on us. ${ }^{9}$ However, while the wind demands an anthropocentric value system, the environmental critic Holmes Rolston III has posed an alternative biocentric axiology through which we can understand this phenomenon. ${ }^{10}$ According to Rolston, an intrinsic biological value can be found in natural processes, a term he calls 'biofunctionalism'. ${ }^{11}$ Contrary to the human desire to attribute value to a naked world, following Rolston's thesis, I will argue that the peculiar nature of the wind and the cultural symbolism of the weathercock brings to light what Jacques Derrida has termed the 'economic circle'. ${ }^{12}$ Here, 'economy' will be understood in the widest sense to denote any exchange of equivalent forms through the act of mediation. Taking the circularity at the heart of the weathercock's structure, I will argue that this meteorological instrument not only allows us to determine the direction of the wind, but that it also reveals an 'economic circle' established between the subject orientated and the natural world. By doing so I will contend that it reveals that value emerges from a position between the subject and object, effectively carried along by the wind.

\section{A Six Pence Per Wind}

In The Philosophy of Money (1907) Georg Simmel described the need to attribute a relative value to the flux of life, attaching it to the absolute. ${ }^{13}$ In this subjectivist axiology he recognised value to emerge at the point when the subject finds 'what is steadfast and reliable behind ephemeral appearances and the flux of events' ${ }^{14} \mathrm{He}$ writes:

The mythologies that posit a thunderer behind the thunder, a solid substructure below the earth to keep it from falling, or spirits in the stars to conduct them in their celestial course - all these are searching for a substance, not only as the embodiment of the perceived qualities and motions, but as the initial active force. An absolute is sought beyond the mere relationships between objects, beyond their accidental and temporal existence. $^{15}$

The need, Simmel recognised, to fix the value of meteorological events to some 'absolute' demands a protagonist, who operates within an ethical nexus attributing value to the surrounding elements. ${ }^{16}$ In this case the blank world in which the human imposes his constituent values is viewed as devoid of 'intrinsic value', until value is accordingly assigned. ${ }^{17}$ In this anthropocentric system, Simmel argues, all is relative: 
Every link depends upon another [...] If the effect that one element produces upon another then becomes a cause that reflects back as an effect upon the former, which in turn repeats the process by becoming a cause of retroaction, then we have a model of genuine infinity in activity. ${ }^{18}$

To segment value from the wind involves a logic by which the mind extracts snapshots from an ever-changing continuum.

It is no surprise that this slicing off of the wind manifested itself as a figurative practice amongst sailors who, up until the early 1900s bought 'winds in the shape of knotted handkerchiefs or threads from old women who claim to rule the storm'. ${ }^{19}$ The wind, as simply 'air in motion', demands this process of compartmentalisation. ${ }^{20}$ In this way, like the peculiar nature of temperature, we recognize the wind in relation to a recording device, through a meteorological instrument, against our skin or our umbrellas as they turn inside out on a windy day. This relational system requires the application of value to a segment of flux, in this case a 'parcel' of the wind. ${ }^{21}$ The practice of buying luck through the purchase of 'good wind' reflects a personal investment in the movement of air. Phrases such as 'windfall', 'go down in wind' and 'raise the wind' all directly attribute the movement of the wind to correlative economic experience, whether bankruptcy or sudden wealth. ${ }^{22}$ This takes its most pointed form in the economics of weather, which, William John Maunder suggests, forces us to 'learn how to live within our climatic income', and correlate the flow of air to economic patterning. ${ }^{23}$ This subjectification of the wind, or desire to value it, emerges from the unique power it has in determining our fate. ${ }^{24}$ In his short story Typhoon (1902), Joseph Conrad described how 'an earthquake, a landslip, an avalanche, overtake a man incidentally, as it were - without passion. A furious gale attacks him like a personal enemy, tries to grasp his limbs, fastens upon his mind, seeks to rout his very spirit out of him. ${ }^{25}$

Although the wind requires an anthropocentric measure, the relationship between the wind and the weathercock signals another economic transaction. Weathervanes originated from flags used aboard vessels. ${ }^{26}$ By the first century BC the Macedonian astronomer Andronikos had built the 'Tower of Winds' in Athens. ${ }^{27}$ This was an octagonal structure, which featured the Sea God Triton poised on top. In the ninth century the cock became the standard form to signal the direction of the wind. ${ }^{28}$ This was enforced when Pope Nicholas I decreed that the symbol of the cock be placed above all religious buildings to remind the faithful of St. Peter's dilemma. ${ }^{29}$ In this biblical passage, Jesus warned Peter that he would betray him three times before the cock crowed at dawn. Therefore, the weathercock, seen from afar, was intended to act as a reminder of the Redemption event and cast the shadow of Judgement Day across the land. ${ }^{30}$ However, as the cock also crowed at the time of the resurrection, the bird was also seen to evoke eternal life, healing and regeneration. ${ }^{31}$ While by the fifteenth century the form of the weathercock had proliferated to include dragons, insignia and scenes of rustic life, its connection to the cockerel and thus to the resurrection and redemption event had been naturalised. ${ }^{32}$ 


\section{The Resurrection of the Cock}

Melville plays on both the resurrection and the redemption story in 'Cock-ADoodle-Doo'. By doing this he ties the noble cock Beneventano (and by default the 'good wind' that he signifies) into a divine economy, extending the transaction of value beyond the threshold of the earthly and into the heavenly realm. ${ }^{33}$ 'Cock-ADoodle-Doo' ends with a resurrection event. Following the cock's death, the narrator steals the cock's avian persona, crowing 'under all circumstances late and early with a continual crow Cock-A-Doodle-Doo! -oo! - oo! -oo! -oo! ${ }^{34}$ Not only does the narrator resurrect the crow in his daily call, but the 'made to order' engraving on the Merrymusk family gravestone allows the crow to achieve eternal life. ${ }^{35}$ Inscribed on the tombstone was not the traditional 'skull and crossbones', but instead 'a lusty cock in the act of crowing. ${ }^{36}$ The epitaph read:

death, where is thy sting?

grave, where is thy victory? ${ }^{37}$

The epigraph chosen by the narrator points to the cockerel's ability to out-crow death, to remove its 'sting' and disband its 'victory'. ${ }^{38}$ Transforming into the cock, the narrator enacts a double resurrection. The cock lives on through the narrator's daily crowing. Furthermore, since the death of the cock the narrator has undergone a regeneration of character. His debts have been cleared and he no longer lives in a 'miserable world'. 39 'Cock-A-Doodle-Doo' thus encapsulates the victory of life after death; death wins at first only for 'life to triumph' once again.

In his book Noli Me Tangere: On The Raising of the Body (2003), Jean-Luc Nancy points to the supernatural order of the resurrection, which, for religion, is 'the renewal of a presence that bears the phantasmic assurance of immortality'. There is 'nothing other than the departing into which presence actually withdraws, bearing its sense in accordance with this parting. ${ }^{40}$ He goes on to suggest that the:

Resurrection is the uprising [surrection], the sudden appearance of the unavailable, of the other and of the one disappearing in the body itself and as the body. This is not a magical trick. It is the very opposite: the dead body remains dead, and that is what creates the "emptiness" of the tomb, but the body that theology will later call "glorious" (that is, shining with the brilliance of the invisible) reveals that this emptiness is really the emptying of presence. $^{41}$

The gravestone reminds us of the cock that has defied death, evoking Nancy's 'empty tomb'. It suggests the departure of Christ's body, and the absenting of presence; a 'Salutation' that affects 'no return'. ${ }^{42}$ While the gravestone indicates the departure of presence for Nancy, Jacques Derrida reads the resurrection not as an absenting of life but as a 'living on', a 'triumph of life' over death. This makes the gravestone a site for 'life' to overflow the boundaries of death. ${ }^{43}$ In his essay 'Living On' (1979), Derrida posits the resurrection event as the flooding of 'life' after life, of life after death. ${ }^{44} \mathrm{He}$ writes, "Living, living on", differs and defers, like "differ(a)nce" beyond identity and difference. ${ }^{45}$ The cock and the good wind partake in this double movement of absence and presence, of departure and return. The weathercock, therefore, stands as an empty tomb: the site for recurring life. 
It is no surprise that the American semiologist C.S. Peirce, pointing to the arbitrariness of the sign, chose the weathercock to emblematise what he termed the 'Object of the sign'. For Peirce, the weathercock is an indexical sign, both physically connected to the wind and representative of it. ${ }^{46}$ The wind is the 'dynamical Object' that operates outside the sign. When the wind acts on the weathercock, rotating its position to denote its dominant direction, the 'dynamical Object' fills the sign. ${ }^{47} \mathrm{Just}$ as in the 'resurrection' the absent tomb makes way for a 'living on', the weathercock acts as a 'dead body', reanimated by the wind. The wind, as the dynamical Object, affects the 'living on' of an absenting - presence; its continual resurrection reconstitutes and reforms the sign.

\section{The Cock's Divine Economy}

Not only does the weathercock partake in an economy of absence and presence, but its association with the redemption event also signifies exchange. In his text The Gift of Death (1992), Derrida considers the divine economy established by man's 'responsibility' to the mysterium tremendum of 'God's absoluteness' ${ }^{48}$ He quotes from Matthew 6:19-21:

Lay not up for yourselves treasures upon earth [...] where moth and rust doth corrupt, and where thieves break through and steal. But lay up for yourselves treasures in heaven [...] where neither moth nor rust doth corrupt $[\ldots]$. For where treasure is, there will your heart be also. ${ }^{49}$

Derrida argues, 'God the Father re-establishes an economy that was interrupted by the dividing of heaven and earth. ${ }^{50}$ This, Derrida suggests (quoting Nietzsche), was "a history of the economy as "the contractual relationship" between creditors and debtors. ${ }^{51}$ The history of religion is based on 'the creditor-playing scapegoat for his debtor'. This, he adds, has created a false history based on the three tenets of 'credit', 'the creditor' and 'credence'; positioned between the divine and earthly realm supported by the promise of redemption. ${ }^{52}$

Throughout 'Cock-a Doodle-Doo!' the tension between the 'creditor' and the 'debtor' is played out both in the earthy sphere, as the narrator tries to thwart his debtor, and the divine sphere, as the narrator hunts the Noble Cock, the Holy Grail. The Holy Grail, a myth that appeared in vernacular literature towards the end of the medieval era, spoke of an extraordinary gift infinitely large and free. The grail was thought to lift the human out of the world of exchange and into one where freedom and totality were possible. ${ }^{53}$ The narrator discovers the bird accidently when arriving at Merrymusk's house to pay his debt, the wood-sawyer's overdue wages. The desperate haggling that ensues between the narrator and Merrymusk results in the narrator bartering with earthly dividends for a 'divine' reward. The negotiation runs as such:

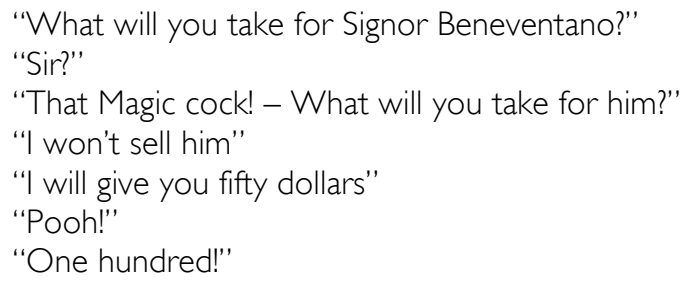




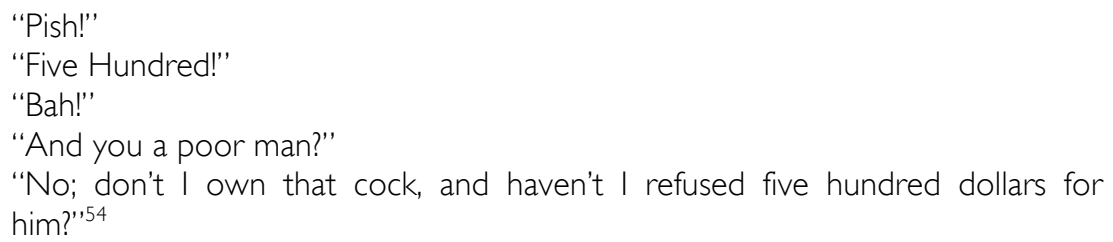

This haggling over the 'Noble Cock', within a barter economy that links the earthly domain to the heavenly realm, posits the bird as the Holy Grail and transforms it into the salvation object. However, as the cock is the 'object of exchange' between earthly and heavenly salvation, it becomes the site for the interchange of value centred on debt and credit, and the departure and return of presence (as it occurs in the resurrection). Posited at the centre of departure and return, debt and credit, the cockerel could be seen to stand at the heart of what Derrida terms 'the economic circle. ${ }^{55}$

\section{The Circular Value of the Wind}

In his text Given Time: Counterfeit Money, Derrida traces the roots of the term 'economy' from its origins in the Greek words nomos (law) and oikos (home, property, family, indoors). He does this to point to the joining of nomos and oikos with the 'idea of exchange, circulation, of return'. ${ }^{56}$ He goes on to add:

The figure of the circle is obviously at the centre, if that can still be said of a circle. It stands at the centre of any problematic of oikonomia, as it does any economic field: circular exchange, circulation of goods, products, monetary signs [...] This motif of circulation can lead one to think that the law of economy is - the circular - return to the point of departure, to the origin, also to the home. ${ }^{57}$

The circular structure at the heart of oikonomia always demands a 'return to the point of departure, to origin, also to the home'. ${ }^{58}$ This circular movement is inscribed in the structure of the winds. It was, after all the Warder of the Winds Aeolus, who imprisoned the winds so as to lead Odysseus home in Homer's Odyssey. ${ }^{59}$ As his parting gift, Aeolus granted Odysseus an oxhide sack containing all the winds except Zephyrus - the westerly wind that would direct Odysseus back to Ithaca. While Ithaca was in view, a band of greedy sailors opened the sack releasing the wrath of the three other winds, causing a storm, which sent them back to the island of Aeolia. ${ }^{60}$ Although the crew ruined the safe passage home with their own 'folly', it is the four winds that drive Odysseus' ship, and function narratively as the agent of return in the Odyssean cycle.

In this way the wind is a crucial vehicle in the oikonomia at the heart of Odysseus' journey, marking a circle that brings the narrative to completion. While the winds incorporate a circular agency, the structure of the weathercock could also be seen to have a circular passage fixed in its structure. This is evident in the symbolism of the cock, which since ancient lore has been afforded the role of timekeeper. Desiderius Erasmus wrote in 1536 of the bird as 'the night watchmen of ours, which nature created to waken mortals to their work and put an end to their sleep $[. .$.$] preventing sunrise from stealing upon us unprepared' { }^{61}$ In 'Cock-ADoodle-Doo' the cock upholds this role by marking the cycle of the narrator's day. He hears his crow resounding 'from the rising of the sun unto the going down 
thereof. ${ }^{62}$ This connection to time also gave the cock an important role in the modern time-keeping strategies: the functional mechanism in the watch was termed 'the cock'. Signalling the moment day turns into night and night into day, the cock's monitoring of time connects him to the circular passage at the centre of oikonomia.

Just as the cockerel symbolises the circular passage of exchange, so the weathercock stands on a pivot, designating the direction of wind through its $360^{\circ}$ span. ${ }^{63}$ Wind is formed when air flows from high to low pressure, producing a current. When the direction of the wind changes, the larger surface of the vane moves with it, so that the wind and vane both move in the same direction. The point where the vane signals the wind the least tension between the cock and the wind exists. Friction is heightened when the wind changes direction, increasing pressure on the surface area of the instrument. During the Romantic period, this exchange between the wind's cadence and the weathercock was demonstrated by the Aeolian harp, an instrument played by the wind. ${ }^{64}$ The instrument was activated by the kinetic energy of air translated into a sonic value. This created an economic exchange between the energy encapsulated in the movement of air (acting as Peirce's 'dynamical Object'), and the structure of the Aeolian Harp ('the Object of the sign'). A similar economic transaction occurs in the circular rotation of the weathercock, between the force of the wind and the sign. Following the economic circle, value is therefore not one-directional but acts within a circular economy. When positioned at the heart of an economic circle, the weathercock extends value beyond human projection and connects 'intrinsic value' inherent in nature to that materialised by the sign. Like the cockerel in Melville's story, which establishes an economy between the earthly and the divine sphere, the weathercock forms a circle between the subject and the object world.

\section{Arbitrating Value}

The economic circle at the heart of the weathercock's structure bridges the divide between subjective and intrinsic value. In this way the economic circle that the cockerel presides over evokes an axiology that extends beyond the anthropocentric model described by Simmel. ${ }^{65}$ Rolston has argued that since subjectivism has eaten up everything, some attention must be given to 'intrinsic biological value'. This comprises the structure of matter and involves processes both inclusive of and separate from human presence. ${ }^{66}$ This, he argues, requires dismantling the primary (fact), secondary (observer dependent), and tertiary (value) qualities elaborated by John Locke. Instead, it must be recognised that tertiary qualities act structurally in nature in the same way as primary or secondary qualities do. ${ }^{67} \mathrm{He}$ writes, 'all judgements mix theory with fact', making judgements of natural value differ little to those of natural facts. ${ }^{68}$ Once attention is paid to what Rolston terms biofunctionism, the atmospheric distribution of the wind acts as a plural system, whereby value is unevenly distributed. ${ }^{69}$ Accordingly, Rolston would attribute the 'intrinsic value' of the wind to its inherent role within atmospheric processes, rather than its value, for example, as a portent from God. In this way Rolston defends a biocentric value philosophy in which intrinsic value is intertwined with instrumental value, and both are products of the same value-producing system. ${ }^{70}$ Energy in the weathercock is therefore transferred between the wind (the movement of air in the atmosphere) and the weathercock, which is, as Peirce 
noted, a sign without a strict utterer. In this way the weathercock 'resurrects' and 'exchanges' value materialised by the wind. Value is dependent both on natural forces (the dynamical Object) and the weathercock (the Object of the sign). ${ }^{71}$

\section{Mary Poppins Returns}

The cockerel presides over the passage from absence to presence, the dead to the living and the living to the dead, day to night and night to day. In this way the weathercock could be seen to represent a value economy that falls in between a subjective and objective axiology. It operates within an 'economic circle'. In the Disney classic Mary Poppins (1964) a weathercock positioned on top of the eccentric neighbours' naval ship in Cherry Tree Lane signals the arrival of that famous 'Ur'-nanny. Its presence reminds us of the exchange between the 'winds that blow' and those that are blown. ${ }^{72}$ In this exchange, value resides both in natural processes, the winds that blow, and in the perceiving constituent subjects, those that are blown. As Poppins does not only read the wind, but is carried off by it, whisked high above the streets of London, the weathercock that signals her arrival assures us of her circular voyage. Like Odysseus, whose journey involves departure with the promise of homecoming, Mary Poppins returns. Indeed, Pamela Lyndon Travers reassures us with the title of her sequel, Mary Poppins Comes Back (1935). However, this time the nanny arrives in place of Michael and Jane's kite, reeled in by the children amidst the racket of the twins who 'were crowing like cocks in the morning. ${ }^{73}$ To cry 'Cock-a-doodle-doo!-oo!-oo!-oo!-oo!', as Melville's narrator does, is thus to wail not for a loss of value. It is, instead, to cry for a value situated no longer in the res cognitans or the res extensa, but at the heart of the 'economic circle'. It is a value located between the objective and the subjective world, spuriously guarded by the Noble Cock Beneventano.

\section{Birkbeck, University of London}

\section{Notes}

John Dryden, 'The Hind and the Panther', in The Works of John Dryden: In Verse, and Prose, With A Life Volume 1 (1687; New York: Harper, 1895), p. 90.

Herman Melville, 'Cock-A-Doodle-Doo, Or The Crowing of the Noble Cock Beneventano', in Billy Budd, Sailor and Other Stories, ed. Harold Beaver (1853; Maryland, Middlesex: Penguin, 1970), p. 107.

Beryl Rowland, 'Melville and the Cock that Crew', American Literature, 52.4 (1981), pp. 593606 (p. 594).

In 'Moby-Dick and Calvinism' Walter Herbert discusses how Melville upset the theocratic system in which he was steeped, working within that paradigm while manipulating it accordingly. I do not have space in this essay to discuss Melville and his complex relationship to Calvinism. See Walter Herbert, Jr., Moby-Dick and Calvinism: A World Dismantled, (New Brunswick, New Jersey: Rutgers University Press, 1977). Jan Deblieu, Wind: How The Flow of Air Has Shaped Life, Myth, And The Land (Boston and New York: Houghton Mifflin Company, 1998), p. 13.

Ibid., p. 15.

Bryan Watson, Heaven's Breath, A Natural History of the Wind (London, Sydney, Auckland, Toronto: Hodder and Stoughton, 1984), p. 76.

As Melville had been a sailor he would have been well aware and sensitive to the power of the wind in determining the sailor's fate. There are many examples of this in his novel Moby 
Dick (1851). One pertinent example occurs when Ishmael enters a small chapel in New Bedford to hear the preacher describe the story of Jonah and the Whale, the archetypal story about God's control over nature. Herman Melville, Moby Dick; or, The Whale, ed. by Tony Tanner (1851; Oxford and New York: Oxford University Press, 1988), pp. 38-50.

Watson, 'Heaven's Breath', p. 240.

Holmes Rolston III, 'Are Values in Nature Subjective or Objective?', Environmental Ethics, 4 (1982), pp. 125-151.

Emyr Vaughan Thompson has argued that Rolston's biocentrism places a human value system over nature, assimilating it back to anthropocentrism. However, my interest lies less in the viability of Rolston's holistic naturalism but in how the value currency it evokes upsets an anthropocentric reading of the wind. Emyr Vaughan Thompson, 'Rolston, Naturogenic Value and Genuine Biocentrism', Environmental Values, 6.3 (1997), pp. 355 360. 'Intrinsic' value has had various denotations which have been used interchangeably. My usage of 'intrinsic value' in this essay follows John O'Neil's definition: 'values that an object possesses independently of the valuations of valuers.' For definitions of 'intrinsic value' see John O'Neil, 'The Varieties of Intrinsic Value', in Environmental Ethics, ed. by Andrew Light and Holmes Rolston III (Oxford: Blackwell, 2003), p. 132.

Georg Simmel, The Philosophy of Money, ed. by David Frisby and Tom Bottomore (1900; London: Routledge, 1990), p. 102.

Ibid.

Ibid.

For more on how the weather has been understood and valued see Vladimir Jankovic, Reading the Skies: A Cultural History of English Weather, 1650-1820 (Chicago: University of Chicago Press, 2001).

J. Baird Callicott, In Defence of The Land Ethic: Essays in Environmental Philosophy (Albany: State University of New York Press, 1989), p. 160.

Simmel, 'The Philosophy of Money', p. 119.

Sir James Frazer, The Golden Bough (1922; Charleston: Forgotten Books, 2008), p. 81.

Watson, 'Heaven's Breath,' p. 240.

Slater Brown, World of The Wind (Indianapolis and New York: The Bobbs-Merrill Company, 1961), p. 11.

Ibid., p. 12.

William John Maunder, The Value of Weather (London: Methuen, 1970), p. 5.

Deblieu, 'Wind', p. 4.

Joseph Conrad, 'Typhoon', in Typhoon and Other Stories (1902; Garden City, New York: Doubleday, Page and Company, 1925), p. 40.

Watson, 'Heaven's Breath', p. 76.

Ibid.

Ibid.

Ibid.

Eric Sloane, Our Vanishing Landscape (London: Wilfred Funk, 1955), p. 96.

Rowland, 'Melville and the Cock that Crew', p. 560.

Brown, 'World of The Wind', p. 119.

Ilana Padres has written about the extensive manipulation of biblical exegesis in Melville's text illustrating both the complex hermeneutic references and the extensive play with varying forms of discursive interpretation in his writing. See Ilana Padres, 'Remapping Jonah's Voyage: Melville's Moby Dick and Kitto's Cyclopedia of Biblical Literature',

Comparative Literature, 57.2 (2005), pp. 135-157. The cock also has an important role in folk law and in Greek thought, best represented by Socrates' famous last words on his deathbed. Melville makes a direct reference to this event in the short story, showing the many different traditions upon which Melville drew in 'Cock-A-Doodle-Doo'. See Rowland, 'Melville and the Cock that Crew', p. 598. Melville, 'Cock-A-Doodle-Doo', p. 128.

Ibid.

Ibid.

Ibid.

Rowland, 'Melville and the Cock that Crew', p. 598.

Melville, 'Cock-A-Doodle-Doo', p. 105. 
Jean-Luc Nancy, Noli Me Tangere: On the Raising of the Body (New York: Fordham University Press, 2008), p. 15.

Ibid., p. 16.

Jean Luc Nancy, 'Consolation, Desolation', in Dis-Enclosure: The Deconstruction of Christianity, trans. by Bettina Bergo, Gabriel Malenfant, Michael B. Smith (London and New York: Fordham University Press, 2008), p. 158.

Jacques Derrida, 'Living On', trans. by James Hulbert, in Deconstruction and Criticism (1979; London and New York: Continuum, 2004), p. 135. In his essay 'Consolation: Desolation', Nancy discusses the 'Preface' Derrida wrote for Each Time Unique: The End of the World (2003). Nancy shows how Derrida understands the 'resurrection' in two ways, both as a poetic awakening of language and as an impossibility, death being the absolute closure of life. As the dead carry with them the entire world, that can never be 'resurrected', Nancy writes, quoting Derrida, " the adieu" should salute nothing other than "the necessity of a possible non-return, the end of the world as the end of any resurrection." Jean Luc Nancy, 'Consolation, Desolation', p. 158.

Derrida, 'Living On', p.136.

Ibid.

Charles Sanders Peirce, 'Pragmatism', in The Essential Peirce, Selected Philosophical Writing, Vol. 2 (1893-1913) (1907; Bloomington: Indiana State University Press, 1998), p. 406.

Jørgen Dines Johansen and Svend Erik Larsen, Signs in Use: An Introduction to Semiotics (London and New York: Routledge, 2002), p. 32.

Jacques Derrida, The Gift of Death, trans. by David Wills (Chicago and London: University of Chicago Press, 1992), p. 98.

Ibid., p. 98.

Ibid., p. 99.

Ibid., p. 113.

Ibid., p.114. Derrida quotes from Freidrich Nietzsche, The Genealogy of Morals, vol. 13, in The Complete Works of Friedrich Nietzsche, ed. by Dr. Oscar Levy (New York: Gordon Press, 1974), p. 111.

Mark Shell, Money, Language and Thought: Literary and Philosophical Economies From the Medieval to the Modern Era (Los Angeles and London: University of California Press, 1982), p. 24.

Herman Melville, 'Cock-A-Doodle-Doo!', p. 126.

Jacques Derrida, Given Time: Counterfeit Money trans. by Peggy Kamuf (1991; Chicago and London: University of Chicago Press, 1992), p. 6.

Ibid.

Ibid., pp. 6-7.

Ibid.

Brown, 'World of Wind', p. 146.

Homer, The Odyssey trans. by Ian Johnston (Arlington, VA: Richer Resources Publications, 2006), p. 182.

Desiderius Erasmus, 'vii 66, Before the Cock Crows Twice', in Adages III to IV ii 100 ed. by John N. Grant and Denis L. Drysdall (1536; Toronto: University of Toronto Press, 2005), p. 257.

Melville, 'Cock-A- Doodle-Doo', p. 108.

Derrida, 'Given Time: Counterfeit Money', p. 7.

Thomas Hankins and Robert J. Silverman, 'The Aeolian Harp and the Romantic Quest of Nature', in Instruments and the Imagination (Princeton: Princeton University Press, 1995), p. 86.

Hankins and Silverman, 'The Aeolian Harp and the Romantic Quest of Nature', pp. 86-113. Rolston III, 'Are Values in Nature Subjective or Objective?', p. 138.

Ibid., p. 132.

Ibid., p. 131.

Ibid., p. 132.

Theodore W. Nunez, 'Rolston, Lonergan, and the Intrinsic Value of Nature', The Journal of Religious Ethics, 27.1 (1999), p. 107. Critics of Rolston's value theory such as Elizabeth Harlow have pointed that, according to the philosophies of David Hume and Ludwig Wittgenstein, intrinsic value cannot be comprehended because reality is now perceived as language dependent. Others such as Theodore W. Nunez point out that Rolston draws 
heavily on a quasi-Catholic transcendentalism that posits the naturalist somewhat above nature. I do not have space in this essay to discuss the facets of Rolston's argument or to address his critics.

Peirce, 'Pragmatism', p. 406.

Mary Poppins, dir. Robert Stevenson (Disney, 1964).

Pamela Lyndon Travers, Mary Poppins Comes Back (1935; Middlesex, New York: Puffin

Books, 1968), p. 19.

\section{Works Cited}

Brown, Slater, World of The Wind (Indianapolis and New York: The Bobbs-Merrill Company, 1961)

Callicott, J. Baird, In Defence of The Land Ethic: Essays in Environmental Philosophy (Albany: State University of New York Press, 1989)

Conrad, Joseph, 'Typhoon', in Typhoon and Other Stories (1902; Garden City, New York: Doubleday, Page and Company, 1925), pp. 85-131.

Deblieu, Jan, Wind: How The Flow of Air Has Shaped Life, Myth, And The Land (Boston and New York: Houghton Mifflin Company, 1998)

Derrida, Jacques, The Gift of Death, trans. by David Wills (Chicago and London: University of Chicago Press, 1992) Given Time: Counterfeit Money, trans. by Peggy Kamuf (1991; Chicago and London: University of Chicago Press, 1992) 'Living On', in Deconstruction and Criticism, trans. by James Hulbert (1979; London and New York: Continuum, 2004), pp. 62-143.

Dryden, John, 'The Hind and the Panther', in The Works of John Dryden: In Verse, and Prose, With a Life, Volume 1, ed. by Rev. John Mitford (1687; New York: Harper, 1859), pp. 85-110.

Erasmus, Desiderius, 'vii 66 Before the Cock Crows Twice', in Adages III to IV ii 100, ed. by John N. Grant and Denis L. Drysdall (1536; Toronto: University of Toronto Press, 2005), pp. 257-259.

Frazer, Sir James, The Golden Bough (1922; Charleston: Forgotten Books, 2008)

Hankins, Thomas, and Robert J. Silverman, 'The Aeolian Harp and the Romantic Quest of Nature', in Instruments and the Imagination (Princeton: Princeton University Press, 1995) pp. 86-113.

Hargrove, Eugene, 'Weak Anthropocentric Intrinsic Value', in Environmental Ethics, ed. by Andrew Light and Holmes Rolston III (Oxford: Blackwell, 2003), pp. 175-191.

Hart, James, and Embree, Lester E., Phenomenology of Value and Valuing (New York: Springer, 1997)

Herbert, Walter, Moby-Dick and Calvinism: A World Dismantled (New Brunswick, New Jersey: Rutgers University Press, 1977)

Homer, The Odyssey, trans. by Ian Johnston (Arlington, VA: Richer Resources Publications, 2006)

Janković, Vladimir, Reading the Skies: A Cultural History of English Weather 1650 1820 (Chicago: University of Chicago Press, 2001)

Johansen, Jørgen Dines, and Svend Erik Larsen, Signs in Use: An Introduction to Semiotics (London and New York: Routledge, 2002)

Maunder, William John, The Value of Weather (London: Methuen, 1970) 
McCarron, Kevin, “I Have Been Dead and I am Alive Again”: Resurrection in the Rehabilitation Narrative', in Resurrection, ed. by Stanley E. Porter, Michael Hayes and David Tomb (London: T \& T Clark, 1999), pp. 350-362.

Melville, Herman, Moby Dick, Or, The Whale, ed. by Tony Tanner (1851; Oxford and New York: Oxford University Press, 1988), pp. 38-50.

Melville, Herman, 'Cock-A-Doodle-Doo, or The Crowing of the Noble Cock Beneventano', in Billy Budd, Sailor and Other Stories, ed. by Harold Beaver (1853; Maryland, Middlesex: Penguin, 1970), pp. 101-129.

Nancy, Jean- Luc, 'Consolation, Desolation', in Dis-Enclosure: The Deconstruction of Christianity, trans. by Bettina Bergo, Gabriel Malenfant, Michael B. Smith (New York: Fordham University Press, 2008), pp. 98-104.

Press, 2008) Noli Me Tangere: On the Raising of the Body (New York: Fordham University

Nunez, Theodore W., 'Rolston, Lonergan, and the Intrinsic Value of Nature', The Journal of Religious Ethics 27.1 (1999), pp. 105- 128.

O'Neil, John, 'The Varieties of Intrinsic Value', in Environmental Ethics, ed. by Andrew Light and Holmes Rolston III (Oxford: Blackwell, 2003), pp. 131143.

Oliver, Egbert S., 'Cock-A-Doodle-Doo and Transcendental Hocus Pocus', The New England Quarterly, 21.2 (1948) pp. 204-216.

Padgin, William Edward, The Story of The Weathercock (London: Appleby, 1949)

Padres, Ilana, 'Remapping Jonah's Voyage: Melville's Moby Dick and Kitto's Cyclopedia of Biblical Literature', Comparative Literature, 57.2 (2005), pp. 135-157.

Peirce, Charles Sanders, 'Pragmatism', in The Essential Peirce, Selected Philosophical Writing, Vol. 2 (1893-1913) (1907; Bloomington: Indiana State University Press, 1998), pp. 398- 434.

Rolston III, Holmes, 'Are Values in Nature Subjective or Objective?', Environmental Ethics, 4 (1982), pp. 125-151. 'Disvalues in Nature' The Monist, 75.2 (1992) pp. 250-278.

Rowland, Beryl, 'Melville and the Cock that Crew', American Literature, 52.4 (1981) pp. 593-606.

Shell, Mark, Money, Language and Thought: Literary and Philosophical Economies From the Medieval to the Modern Era (Los Angeles and London: University of California Press, 1982)

Simmel, Georg, The Philosophy of Money, ed. by David Frisby and Tom Bottomore (1900; London: Routledge, 1990)

Sloane, Eric, Our Vanishing Landscape (London: Wilfred Funk, 1955)

Thompson, Emyr Vaughan, 'Rolston, Naturogenic Value and Genuine Biocentrism', Environmental Values, 6.3 (1997), pp. 355-360.

Travers, Pamela Lyndon, Mary Poppins Comes Back (1935; Middlesex, New York: Puffin, 1968)

Watson, Bryan, Heaven's Breath, A Natural History of the Wind (London, Sydney, Auckland, Toronto: Hodder, Stoughton, 1984)

Film

Mary Poppins, dir. by Robert Stevenson (Disney, 1964) 